\title{
Correction to: Keys to success of a community of clinical practice in primary care: a qualitative evaluation of the ECOPIH project
}

David Lacasta Tintorer ${ }^{1,2,3}$, Josep Maria Manresa Domínguez ${ }^{2,3}$, Enriqueta Pujol-Rivera ${ }^{4}$, Souhel Flayeh Beneyto ${ }^{1}$, Xavier Mundet Tuduri ${ }^{3,5}$ and Francesc Saigí-Rubió ${ }^{*}$ (i)

\section{Correction to: BMC Fam Pract (2018) 19:56 \\ https://doi.org/10.1186/s12875-018-0739-0}

Following publication of the original article [1], the authors opted to update affiliation 3 in order to comply with the current regulations for the submission of Doctoral Thesis by compendium of articles, the Universitat Autónoma de Barcelona Doctoral School asks us to update the affiliation number 3, adding "Departament de Medicina" at the beginning, as follows:

3 Departament de Medicina, Universitat Autònoma de Barcelona, Plaça Cívica, s/n, 08193 Bellaterra, Cerdanyola del Vallès, Spain.

\section{Author details}

${ }^{1}$ Centre d'Atenció Primària Gran Sol, Gerència d'Àmbit d'Atenció Primària Metropolitana Nord, Institut Català de la Salut, Avinguda del Doctor Bassols, 112 - 130, 08914 Badalona, Spain. ${ }^{2}$ Unitat de Suport a la Recerca Metropolitana Nord, IDIAP Jordi Gol. CAP El Maresme, Camí del Mig, 36 planta 4a, 08303 Mataró, Spain. ${ }^{3}$ Departament de Medicina, Universitat Autònoma de Barcelona, Plaça Cívica, s/n, 08193 Bellaterra, Cerdanyola del Vallès, Spain. ${ }^{4}$ Institut Universitari d'Investigació en Atenció Primària (IDIAP Jordi Gol), Gran Via Corts Catalanes, 587, àtic, 08007 Barcelona, Spain. ${ }^{5}$ Unitat de Suport a la Recerca Barcelona Ciutat, IDIAP Jordi Gol, Carrer Sardenya 375, 08025 Barcelona, Spain. ${ }^{6}$ Faculty of Health Sciences, Universitat Oberta de Catalunya, Barcelona. Av. Tibidabo, 39-43, 08035 Barcelona, Spain.
Published online: 17 April 2020

\section{Reference}

1. Lacasta Tintorer D, Manresa Domínguez JM, Pujol-Rivera E, et al. Keys to success of a community of clinical practice in primary care: a qualitative evaluation of the ECOPIH project. BMC Fam Pract. 2018;19:56 https://doi. org/10.1186/s12875-018-0739-0.

The original article can be found online at https://doi.org/10.1186/s12875018-0739-0

*Correspondence: fsaigi@uoc.edu

${ }^{6}$ Faculty of Health Sciences, Universitat Oberta de Catalunya, Barcelona. Av.

Tibidabo, 39-43, 08035 Barcelona, Spain

C The Author(s). 2020 Open Access This article is licensed under a Creative Commons Attribution 4.0 International License, which permits use, sharing, adaptation, distribution and reproduction in any medium or format, as long as you give appropriate credit to the original author(s) and the source, provide a link to the Creative Commons licence, and indicate if changes were made. The images or other third party material in this article are included in the article's Creative Commons licence, unless indicated otherwise in a credit line to the material. If material is not included in the article's Creative Commons licence and your intended use is not permitted by statutory regulation or exceeds the permitted use, you will need to obtain permission directly from the copyright holder. To view a copy of this licence, visit http://creativecommons.org/licenses/by/4.0/ The Creative Commons Public Domain Dedication waiver (http://creativecommons.org/publicdomain/zero/1.0/) applies to the data made available in this article, unless otherwise stated in a credit line to the data. 